\title{
CONSTRUCTING TEACHER'S SELF-ASSESSMENT OF RAPPORT BUILDING IN EFL CLASSROOM
}

\author{
Muhamad Nova \\ English Education Department, Universitas Pendidikan Indonesia \\ mohnova@student.upi.edu
}

First draft received: 4 November 2016

Final proof received: 18 February 2017

\begin{tabular}{l} 
Abstract \\
A good education is not only about academics, but also the positive social interaction in classroom. \\
Therefore, there is a need to build rapport in classroom interaction. In building rapport, EFL teachers \\
need to conduct several activities, and through self-assessment, teachers can monitor and evaluate \\
their own teaching for professional development. However, self-assessment instrument for building \\
rapport has not been developed yet by any researchers. To fill the needs, this study is established to \\
construct a self-assessment for teacher in building rapport in EFL classroom. By applying design \\
research from a curriculum perspective, the results revealed a self-assessment instrument of \\
maintaining rapport for EFL teacher. The Cronbach's alpha coefficient ( $\alpha=.928$ ) of this instrument \\
indicated high reliability and the instrument can be considered a reliable instrument to be used for the \\
study sample. EFL teachers can do self-monitoring and self-evaluation on their rapport building in \\
classroom interaction. Additionally, further research in investigating the effect of using this instrument in \\
assessing teacher's quality is required. \\
Keywords: rapport; rapport in EFL classroom; teacher's self-assessment; teacher development \\
\hline \hline \\
To cite this paper (in APA style): \\
Nova, M. (2017). Constructing teacher's self-assessment of rapport building in EFL classroom. \\
International Journal of Education, $9(2), 89-96$. doi: dx.doi.org/10.17509/ije.v9i2.5462
\end{tabular}

A good education is not only about academics, but also the positive development in social interaction (Bruney, 2012) since teaching is essentially a process of interaction between teacher and students in a social setting (Çakir, 2010). Establishing a good communication between teacher and students is a step of successful teaching and learning (Barmaki, 2014), and therefore maintaining the teacher-student relationship is a concern in classroom to foster positive development on students learning in classroom (Bruney, 2012; Nguyen, 2007; Pianta, Hamre, \& Allen, 2012). This teacher and students' relationship is defined as a rapport in which there is a positive, enjoyable, and respectful relationship (Harmer, 2007a; 2007b) and includes harmonious interaction and communication between teacher and students (Bernieri, 1998) in building trust and respects that leads the students to feel capable, competent, and creative in learning (Brown, 2001).

The language learning process in the classroom can be facilitated through teacher and students' interaction. In Nguyen's study (2007), it is revealed that EFL teacher can use target language in giving instruction and guidance to the students and the students learn the target language and use the target language to communicate with the teacher. As the goal of language learning is to use language (Burns, \& Richards, 2012; Johnson, 2001) and to create and maintain social interaction (Nguyen, 2007), building rapport can be an effective way in communicating with students in target language to encourage them in learning (Swenson, 2010; Webb \& Barett, 2014). Therefore, the relationship between teacher and students can be categorized as a crucial factor in the process of the acquisition of a second language for the students (Sánchez et al., 2013) since the target language is seldom used outside the classroom, and the only input and language use is in classroom interaction especially in teacher-student interaction (Suryati, 2015). As a result, a positive relationship between teacher and students is needed to build a good language learning environment in the classroom.

One way to maintain the teacher-students relationship is through having positive interaction between teacher and students. Interaction between the teacher and the students determines the success of teaching and learning activity (Bruney, 2012). Good classroom interaction is categorized as an important factor in student learning and enhancing effective teaching and learning activity (Özer, Atik, Şad, \& Kiş, 2015; Swenson, 2010; Webb \& Barett, 2014). It gives positive impact on teacher's effectiveness and students' learning (Pianta et al., 2012; Sánchez, González, \& Martínez, 2013; Swenson, 2010). Bruney's study (2012) reveals the presence of the classroom interaction in the classroom affects the students' view of teacher's performance in arranging activity and establishing any activities in classroom will not be effective if the relationship between the teacher and the students is not established well. Positive classroom interaction makes the students gain higher achievement (Nguyen, 2007) and create positive attitude from the students toward the learning activity (Pianta et al., 2012). Another study, conducted by Sánchez et al. (2013), reveals a positive teacher-student relationship influences students' motivation in learning in which 
students feel more confident and comfortable to approach teacher and share personal and academic issues. If the students feel they have a good relationship with the teacher, they will feel comfortable and motivated to pay attention to the teacher (Pianta et al., 2012; Sánchez et al., 2013). It has been shown by studies that positive rapport between teacher and students brings positive impact to teaching and learning activity.

Related research of strategies in maintaining the teacher-students' rapport has also been conducted by Bruney (2012) who investigated the process of the teacher-student relationship influencing the development of trust and emotional intelligence in the elementary classroom. Through conducting interview with two experienced teachers in the Greater Toronto Area, this study revealed that the presence of the teacher in the classroom affects the students' view of teacher's performance. This study also suggested 3 effective strategies in maintaining the teacherstudents relationship, by (1) sharing personal feelings; (2) seeking help for the students; and (3) storytelling.

Similar research was also conducted by Pianta et al. (2012). They conducted a study on investigating the concept of interactions and engagement and how to improve teacher-student interactions. Their study revealed four concepts in maintaining teacher-student relationships and interactions: (1) evaluating background knowledge and cognitions of interactions; (2) establishing ongoing relational supports; (3) giving regular individual feedback; and (4) being focus in changing interactions.

Another study was also conducted by Sánchez et al. (2013). Their study investigated the impact of teacher-students relationship on EFL learning. This study revealed information about the issues involved in building a positive teacher-student relationship, and its influence on students' motivation. This study advises that the teacher needs to build trust to make students feel more confident and comfortable to approach the teacher and share personal and academic issues.

In fact, building rapport is not an easy task for EFL teacher to be established in teaching and learning activity (Gebhard, 2009; Webb \& Barett, 2014). Even though it will be automatically maintained after some periods of time (Swenson, 2010), especially in face-to-face meeting (Coutrim, 2016; Murphy \& Manzanares, 2012), mostly EFL teachers still face many difficulties in maintaining the rapport. Gebhard (2009) exposed the teacher's problem in managing classroom interaction. In his book, Gebhard (2009) mentioned 3 problems faced by English teacher in classroom interaction; (1) the teacher feels having not enough time to talk with the students since the teacher mostly cannot manage the time well; (2) the teacher faces limited English speaker students so that the interaction does not run well; and (3) the teacher cannot remember students' name and remembering name is the problem faced by almost all teachers who manage big classroom.

In order to build the rapport, a teacher may provide himself or herself with self-assessment. Many researchers believed that self-assessment raises learners' awareness to do self-monitoring to their progress (e.g. Baniabdelrahman, 2010; Butler \& Lee, 2010; Egodawatte, 2010; Harris, 1997; Kato, 2009;
Meihami \& Razmjoo, 2016; Srimavin \& Darasawang, 2004), to be self-motivated (Butler \& Lee, 2010; Ross, 2006; Srimavin \& Darasawang, 2004), and to be selfdirected in learning (Butler \& Lee, 2010; Harris, 1997; Kato, 2009), and it is also applicable for teacher's professional development (Airasian \& Gullickson, 1994; Ross \& Bruce, 2007). Teachers mostly act without being aware of why they do what they have been doing in classroom (Çimer, Çimer, \& Vekli, 2013), and self-assessment can help the teacher becomes aware of the needs in establishing teaching and learning activity and help them to improve their performance in teaching (Avalos, 2011; Montgomery \& Baker, 2007; Ross \& Bruce, 2007). By doing selfassessment in teaching, teachers can do selfreflection to analyze the classroom situation and take more responsibility for their future actions in class (Airasian \& Gullickson, 1994). Providing necessary support, such as self-assessment, for the teachers may be enough to keep them motivated in teaching (Lumpe, Haney, \& Czerniak, 2000).

However, a self-assessment instrument for building rapport has not been developed yet by any researchers. To fill this gap, this study is established to construct a self-assessment for teacher in building rapport in EFL classroom. EFL teachers can do selfreflection and self-evaluation on their teaching through the instrument developed and find ways to enhance positive rapport to foster positive learning environment.

\section{LITERATURE REVIEW}

In building a rapport, a teacher needs to concern two factors influencing the rapport development. One factor influencing rapport the most is respect. Respect is a vital factor in dealing with any kind of problem behavior that appears in classroom (Harmer, 2007a; 2007b). Any problem behavior may appear because of the unrealistic learning goal set in the classroom which can be too difficult or too easy for the students. Being realistic with the learning goal is a way to give respect to the students who have different levels in learning and language acquisition (Scott \& Ytreberg (2000). Brown (2001) added that giving respect to their ideas is also necessary to maintain good rapport. It includes the attitude of the teacher in responding the students' talk. The way of teacher talk to students influences the respect of students (Harmer, 2007a; 2007b). One example of teacher talk commonly happened in classroom is in giving feedback. Teacher needs to consider correcting the mistakes carefully without losing any positive effort from the students (Paul, 2006) since not all students are happy to be corrected, but some of them need more support and positive reinforcement (Harmer, 2007a; 2007b). Therefore, positive feedback which motivates the students without making them feel down is needed to be enhanced in classroom (Paul, 2006). Besides teacher talk, another aspect needed to be recognized is teacher's gestures. Gesture, expression, and mime should be appropriate with the language use in classroom (Harmer, 2007a; 2007b). Eye contact needed to show interest and attention toward students' talk (Levine \& Adelman, 1982) and giving smile build a positive atmosphere around classroom (Paul, 2006). Therefore, a teacher who gives respect to students will show positive attitude 
towards them and be respectful in handling any problems in classroom (Harmer, 2007a; 2007b).

Another factor gives big influence to rapport development is fairness. Scott \& Ytreberg (2000) stated that being fair is also necessary in building relationship with the students since the students can sense the unfairness from the teacher. Since they are learning a language, they need to have equal chance to practice their language and to be assist by the teacher (Harmer, 2007a; 2007b) whether they are active or inactive learner, and good or bad learner (Paul, 2006). It is necessary for the teacher to give a fair attention to each student in the classroom, not only focusing on the bad one, but also concern with the good one (Paul, 2006). Treating the students equally is helpful in establishing and maintaining rapport (Harmer, 2007a; 2007b).

To maintain the rapport, the EFL teacher needs to find appropriate strategies to be implemented in the classroom. Some strategies in maintaining teacher-students rapport has been developed by experts. Brown (2001) recommends 7 activities to teacher in establishing the teacher-students' relationship by (1) showing interest in each student as a person; (2) giving feedback on each person's progress; (3) openly soliciting students' ideas and feelings; (4) valuing and respecting what students think and say; (5) laughing with them and not at them; (6) working with them as a team and not against them; and (7) developing a genuine sense of vicarious joy when they learn something or otherwise succeed (pp. 203).

Additional activities in building rapport are also promoted by Harmer (2007a; 2007b). He promotes 4 activities the teacher can use to foster the relationship between the teacher and the students and also develop a successful classroom interaction by (1) recognizing the students' name, character, and background; (2) listening properly to the students as an individual; (3) having respect to the students; and (4) being equal and fair in treating and giving attention to the students (pp. 113-115).

\section{METHOD}

This study was a Design Research study. van den Akker (1999) mentioned the aim of Design Research is "not to elaborate and implement the complete interventions, but to come to (successive) prototypes that increasingly meet the innovative aspirations and requirements" (p. 7). The aim of Design Research can be specified in two more specific goals: (1) providing ideas (suggestions, directions) for optimizing the quality of the product to be developed; and (2) generating, articulating and testing design principles (van den Akker, 1999, p. 5). Since its purpose is not to elaborate and implement the product, the process of Development Research is often cyclic or spiral, including analysis, design, evaluation and revision activities, until a satisfying balance between ideals and realization has been achieved (van den Akker, 1999). To fulfill the principle of Design Research, a design research guideline from curriculum perspective from McKenney, Nieveen \& van den Akker (2006) was applied. This guideline provides 5 steps in conducting design research from curriculum perspective, including (1) Explicit conceptual framework, (2) Congruent study design,
(3) Triangulation, (4) Inductive and deductive data analysis, and (5) Full description.

In conducting the study, there were two main participants involved: expert judges and EFL teachers. Two Expert judges from the expertise of English language teaching and assessment were selected to participate in validity testing. $57 \mathrm{EFL}$ teachers who came from different educational institutions were randomly selected and contacted to participate in reliability testing, with the following distributions of school levels: junior high school $(31.58 \%)$, senior high school $(43.86 \%)$, and vocational school (24.56\%), and consisted of 12 males and 45 females.

\section{FINDINGS AND DISCUSSION \\ Explicit conceptual framework}

Based on the related studies and literature mentioned in the previous section, it is recommended that EFL teacher should build the rapport in teaching and learning activities which can create effective learning activity (Bruney, 2012; Özer et al., 2015; Pianta et al., 2012; Sánchez et al., 2013; Swenson, 2010; Webb \& Barett, 2014), gain students' interest in being involved in learning (Pianta et al., 2012; Sánchez et al., 2013; Swenson, 2010; Webb \& Barett, 2014), and motivate the students to be confident and brave to use English (Nguyen, 2007; Pianta et al., 2012; Sánchez et al., 2013; Suryati, 2015). Therefore, there is a need to enhance rapport building in classroom.

A draft of building rapport principles in EFL classroom was proposed based on the related studies and literature. The draft consisted of 11 principles in building rapport; (1) recognizing students (Harmer, 2007a; 2007b); (2) working cooperatively (Brown, 2001); (3) building trust (Bruney, 2012; Sánchez et al., 2013); (4) being fair and equal (Bruney, 2012; Harmer, 2007a; 2007b; Scott \& Ytreberg, 2000); (5) sharing idea (Brown, 2001); (6) sharing feeling (Bruney, 2012); (7) sharing experience (Bruney, 2012); (8) sharing humor (Brown, 2001); (9) listening properly (Brown, 2001; Harmer, 2007a; 2007b; Pianta et al., 2012); (10) expressing non-verbal communication (Brown, 2001; Levine \& Adelman, 1982; Paul, 2006); and (11) giving feedback (Brown, 2001; Harmer, 2007a; 2007b; Pianta et al., 2012).

\section{Congruent study design}

The idea of enhancing teacher's self-assessment was promoted since self-assessment is also applicable for teacher's development (Ross \& Bruce, 2007). Selfassessment can help the teacher become aware of the needs in establishing teaching and learning activity and help them improve their performance in teaching (Avalos, 2011; Montgomery \& Baker, 2007; Ross \& Bruce, 2007). By doing self-assessment in teaching, teacher can do self-reflection to analyze the classroom situation and take more responsibility for their future actions in class (Airasian \& Gullickson, 1994). Self-assessment also contributes to teachers' beliefs about their ability to improve students' learning, and the teacher becomes more confident about their future performance since they believe that through their own actions they have helped students in learning (Ross \& Bruce, 2007). Providing necessary support, such as self-assessment, for the 
teacher may be enough to keep them motivated in teaching (Lumpe, Haney, \& Czerniak, 2000). Therefore, a self-assessment in building rapport can be a solution for teacher to develop their quality in teaching and create an effective learning activity.

An instrument used for a teacher's selfassessment in building rapport was developed based on the conceptual framework of principles of rapport building in classroom. From the 11 principles of building rapport, 35 items were constructed; 3 items for each principle, except for being fair and equal (consisted of 5 items), sharing humor (consisted of 2 items), and giving feedback (consisted of 4 items). A 4-point Likert scale was used to respond to each item of the instrument; strongly disagree $(=1)$, disagree $(=2)$, agree $(=3)$, and strongly agree $(=4)$. Oscarson (1997, in Butler \& Lee, 2010) mentioned that if the items of questionnaire are constructed in respondents' first language, the respondents can more accurately self-assess their performance compared to when the items are delivered in their target language. Therefore, the questionnaire survey was constructed in Bahasa Indonesia since this study investigated Indonesian EFL teachers.

\section{Triangulation}

Triangulation is used to test the instruments' validity and reliability. For instrument's validity, the instrument was delivered to the experts and was assessed by the experts to find the content validity, construct validity, and face validity. Comments were given and the instrument was then revised. The revised version of the instrument was then distributed to EFL teachers for reliability test. Instrument's reliability was tested by $57 \mathrm{EFL}$ teachers from various institutions. The EFL teachers were required to complete the survey in approximately 10-15 minutes. Besides, a simple interview was also conducted to investigate whether the activities provided in questionnaire survey are essential in building rapport.

\section{Inductive and deductive data analysis}

All collected data were then analyzed through SPSS 19.0. The reliability analysis was conducted, and the overall Cronbach's alpha coefficient of the instrument was .928. Because it was higher than .8 (the rational goal of internal consistency) (Gliem \& Gliem, 2003), the instrument can be considered as a reliable instrument to be used for study sample.

\section{Full description}

An instrument of teacher's self-assessment of rapport building has been developed. It consists of 11 sections which represent the eleven principles of rapport building and 35 statements. The complete self-assessment instrument can be seen in Appendix 1.

The first section is recognizing students. Three statements are included in this section which indicate teacher's awareness in recognizing students through three ways, by (1) greeting them, (2) calling them with their name, and (3) knowing their ability. Allday and Pakurar (2007) revealed that greeting the students at the door of classroom, with their name and praise them, increases student on-task behavior. It shows that greeting students give positive effect on their learning. Besides greeting, recognizing their names is also necessary to establish good rapport with students since it makes them feel pleased (Harmer, 2007a; 2007b). It is fundamental to develop a positive sense of community in the classroom and it gives an impression that the teacher cares about their success and develops a sense of trust (Glenz, 2014). Harmer (2007a; 2007b) also mentioned that by "knowing their names is also about knowing about students" (p. 26; p. 114). Therefore, there is a need to know their ability in order to set the learning outcome based on their knowledge (Harmer, 2007a) and awareness about students' characteristic and ability (Manning, 2006).

The second section is working cooperatively. Three statements are included in this section, which indicate teacher's awareness of having cooperativeness with the students. Brown (2001) mentioned one way to connect positive rapport in the classroom is by working with the students as a team, and not against them. Teamwork creates positive relationships which are necessary for knowledge sharing and effective discussion (Georgiadou, Siakas, \& Berki, 2006). Working cooperatively with students as a team makes the students tend to be less disruptive behavior in class, be more positive, have supportive relationships, and have more positive attitudes toward learning activity (Felder \& Brent, 2007). The interaction between teacher and students will raise students' effort (Davis, 1999) and foster their engagement in learning (Brank \& Wylie, 2013).

The third section is building trust. Three statements are included in this section, which indicate teacher's awareness of having trust on their students. The trust between teacher and students is essential as a fundamental concept of effective learning (Özer et al., 2015). Trusting the student makes student feel more confident and comfortable to approach the teacher and share personal and academic issues with the teacher (Sánchez et al., 2013; Bruney, 2012). Having trust in the classroom creates a safe environment for learning in which "students can grow and learn and develop personally, socially, emotionally, and academically under the direction of their teacher" (Bruney, 2012, p. 48) and the teacher can "spend less time with classroom management issues" (Bruney, 2012, p. 33).

The fourth section is being fair and equal. Five statements are included in this section, which indicate teacher's awareness of being equal and fair in treating their students in classroom. Scott \& Ytreberg (2000) stated that being fair is also necessary in building relationship with the students since the students can sense the unfairness from the teacher. Since they are learning a language, they need to have equal chances to practice their language and to be assist by the teacher (Harmer, 2007a; 2007b), whether they are active or inactive learners, and good or bad learners (Paul, 2006). It is necessary for the teacher to give a fair attention to each student in the classroom, not only focusing on the bad ones, but also concern with the good ones (Paul, 2006). Treating the students equally is helpful in establishing and maintaining rapport (Harmer, 2007a; 2007b), and it contributes to enhance a balance amount of interaction between students and the teacher in classroom (Sánchez et al., 2013).

The fifth section is sharing idea. Three statements are included in this section, which indicate a teacher's awareness of sharing their idea with 
his/her students and vice versa. By asking for students' ideas and thoughts and also providing opportunities for students to share their idea (Pianta et al., 2012), the students can express their ideas and opinions (Sánchez et al., 2013), and the teacher should help the students to elaborate their ideas more (Suryati, 2015).

The sixth section is sharing feeling. Three statements are included in this section, which indicate teachers' awareness of sharing their feeling with their students and vice versa. Sharing feeling with students encourages the students to trust and learn from the teacher (Bruney, 2012), and they will feel more confident and comfortable to approach the teacher and share personal and academic issues with the teacher (Sánchez et al., 2013; Bruney, 2012). Furthermore, when a student shares his or her feelings, it makes a positive perspective toward the teacher (Wrenn \& Wrenn, 2009) and their feelings and opinions should be valued (Bruney, 2012).

The seventh section is sharing experience. Three statements are included in this section, which indicate teachers' awareness of sharing their experience with their students and vice versa. Sharing experiences with students increases students' interest in the relevance of the material into real life contexts (Wrenn \& Wrenn, 2009). Gordon (2009 in Wrenn \& Wrenn, 2009) suggested that "teachers should promote experiences that require students to become active learners" (p. 260). Sharing experience may promote awareness of learning responsibility (Tinto, 2003), in which experience shared should be followed by reflection on previous learning to transform the students' previous understanding into some applicable manners (Wrenn \& Wrenn, 2009) for further learning.

The eighth section is sharing humor. Two statements are included in this section, which indicate teachers' awareness of sharing humor and laugh with their students in classroom. Humor can be used for reducing stress (MacAdam, 1985; Steele, 1998), relieving monotonous and boredom classroom, helping students stay tuned in learning, keeping their attention, and building their confidence (Lovorn, 2008), which unlocks social barriers between teacher and student (MacAdam, 1985) and creates a more positive classroom environment (Steele, 1998). When students laugh, "They experience pleasure with a sense of openness to discussion and interaction" (Lovorn, 2008, p. 2). Therefore, humor can be used as an effective way to deal with any difficult situations in classroom (Lovorn, 2008) and establish a positive climate in classrooms (Steele, 1998).

The ninth section is listening properly. Three statements are included in this section, which indicate teachers' awareness of listening to their students properly and intensively. The teacher needs to listen properly to the students as an individual to make a reflection on the way of hs/her teaching, whether the technique is being liked by the students, any activities motivate the students to learn, or the students' reaction on the teacher's teaching style (Harmer, $2007 \mathrm{a} ; 2007 \mathrm{~b})$. The importance of listening and paying attention to students' explanations contributes to build an equal communication between teacher and the students (Sánchez et al., 2013).

The tenth section is expressing non-verbal communication. Three statements are included in this section, which indicate teachers' awareness of expressing their non-verbal communication to their students. Nonverbal communication, including facial expression, eye contact, tone of voice, body postures, and gestures (Ozieblo, 2013; Stamatis, 2011), is often used for gaining attention (Geng, 2011) and emphasizing the meaning of words in utterance (Harmer, 2007b; Levine \& Adelman, 1982) in face-toface interactions (Ozieblo, 2013). To be successful in communication, especially in teaching, teacher needs to be able in using not only the verbal communication but also in non-verbal communication (Behjat, Bayat, \& Kargar, 2014), such as having eye contact to gain students' attention and positive attitude toward teacher, giving smile to affect students' positive perception of the teacher (Beebe, 1980), or using facial expression to express certain emotion and feeling (Ozieblo, 2013).

The eleventh section is giving feedback. Four statements are included in this section, which indicate teachers' awareness of providing feedback on students' performance in classroom. Feedback can be used to raise students' awareness of their errors (Abdollahifam, 2014; Kazemipour, 2014; Maarof, Yamat, \& Li, 2011). Feedback plays an important role in motivating students for further learning, which informs them about their learning progress and their improvement for the weaknesses (Abdollahifam, 2014; Alavi \& Kaivanpanah, 2007; Maarof et al., 2011; Tran, 2007). Therefore, the teacher needs to ensure that the students receive "immediate, unambiguous, and meaningful feedback" (Davis, 1999 , p. 2) which is positive and motivates the students (Paul, 2006) and does not hurt students' feeling (Abdollahifam, 2014).

\section{CONCLUSION}

Teacher's self-assessment of rapport building can be used as an instrument in assessing EFL teacher's development and professionalism, especially in building and maintaining rapport in EFL classroom. By using the instrument, the EFL teachers can do self-reflection and self-evaluation on their teaching and finds ways to enhance positive rapport to foster positive learning environment. Besides, it can also be used as an awareness tool for the teacher on conducting teaching and learning activity which maintains rapport in the classroom.

Nevertheless, this study has some limitations which can affect the effectiveness of the use of the instrument. First, the small amount of sample may be a consideration in instrument's reliability. Therefore, a bigger amount of sample is needed to test the validaty and reliability of the instrument in assessing teacher in rapport building in EFL classroom. Second, the sample of study taken was from Indonesia. Different strategies and techniques in building relationship with students used by EFL teacher may influence the result of applicability of this instrument. Different cultures and different perspectives in using non-verbal communication can affect the teaching and learning process. Therefore, reliability of instrument in other cultures is needed to validate the instrument to be widely used in EFL teaching and learning classroom. Further research is also needed to be conducted on the effectiveness of implementing teacher's self-assessment in rapport building to 
evaluate whether the instrument is considered a useful strategy for promoting rapport building.

\section{ACKNOWLEDGEMENT}

The research is funded by Indonesia Endowment Fund (LPDP).

\section{REFERENCES}

Abdollahifam, S. (2014). Investigating the effects of interactional feedback on EFL students' writings. Procedia - Social and Behavioral Sciences, 98, 16-21. doi:10.1016/j.sbspro.2014.03.383

Airasian, P. W. \& Gullickson, A. (1994). Examination of teacher self-assessment. Journal of Personnel Evaluation in Education, 8, 195-203. doi:10.1007/BF00972263

Alavi, S. M. \& Kaivanpanah, S. (2007). Feedback expectancy and EFL learners' achievement in English. Journal of Theory and Practice in Education, 3(2), 181-196. Retrieved from http://files.eric.ed.gov/fulltext/ED502022.pdf

Allday, R. A. \& Pakurar, K. (2007). Effects of teacher greetings on student on-task behavior. Journal of Applied Behavior Analysis, 40(2), 317-320. doi:10.1901/jaba.2007.86-06

Avalos, B. (2011). Teacher professional development in teaching and teacher education over ten years. Teaching and Teacher Education, 27, 1020. doi:10.1016/j.tate.2010.08.007

Baniabdelrahman, A. A. (2010). The effect of the use of self-assessment on EFL students' performance in reading comprehension in English. The Electronic Journal for English as a Second Language, 14(2). Retrieved from http://files.eric.ed.gov/fulltext/EJ899764.pdf

Barmaki, R. (2014). Nonverbal communication and teaching performance. Proceedings of the 7 th International Conference on Educational Data Mining (EDM) 2014, 441-443. Retrieved from http://educationaldatamining.org/EDM2014/uplo ads/procs2014/YRT/441_EDM-2014-FullProceedings.pdf

Beebe, S. A. (1980). The role of nonverbal communication in education: Research and theoretical perspectives. Paper presented at the 66th Annual Meeting of the Speech Communication Association. Retrieved from http://files.eric.ed.gov/fulltext/ED196063.pdf

Behjat, F., Bayat, S., \& Kargar, A. A. (2014). An investigation of students' attitudes on teachers' nonverbal interaction in Iranian EFL classrooms. International Journal of Language and Linguistics, 2(6-1), 13-18. doi:10.11648/j.ijll.s.2014020601.13

Bernieri, F. J. (1988). Coordinated movement and rapport in teacher-student interactions. Journal of Nonverbal Behavior, 12(2), 120-138. doi:10.1007/BF00986930

Brank, E. \& Wylie, L. (2013). Let's discuss: Teaching students about discussions. Journal of the Scholarship of Teaching and Learning, 13(3), 23 -32 . Retrieved from http://files.eric.ed.gov/fulltext/EJ1017045.pdf

Brown, H. (2001). Teaching by principles: an interactive approach to language pedagogy. Englewood Cliffs: Prentice Hall.

Bruney, G. (2012). The teacher-student relationship: the importance of developing trust and fostering emotional intelligence in the classroom

(Research Paper, University of Toronto, 2012).

Retrieved from

https://tspace.library.utoronto.ca/bitstream/1807/

35096/1/Glenda\%20 MTRP\%20Complete.pdf

Burns, A. \& Richards, J. C. (2012). The Cambridge guide to pedagogy and practice in second language teaching. Cambridge: Cambridge University Press.

Butler, Y. G., \& Lee, J. (2010). The effects of selfassessment among young learners of English. Language Testing, 27(1), 5-31. doi: $10.1177 / 0265532209346370$

Çakir, İ. (2010). Criticizing ourselves as teachers through observation: From reflective to effective teaching. English for Specific Purposes World, 9(30), 1-12. Retrieved from https://www.espworld.info/Articles_30/Cakir.pdf

Çimer, A., Çimer, S. O., \& Vekli, G. S. (2013). How does reflection help teachers to become effective teachers? International Journal Educational Research, 1(4), 133-149. Retrieved from

https://ijsse.com/ijer/sites/default/files/papers/20 13/v1i4/Paper-1.pdf

Coutrim, E. D. C. M. (2016). Foreign language acquisition on the web: What teacher? What student? What language? ETD - Educação Temática Digital, Campinas, SP, 18(3), 553-563. doi:10.20396/etd.v18i3.8646110

Davis, B. G. (1999). Cooperative learning: Students working in small groups. Speaking of Teaching, 10(2), 1-4. Retrieved from https://web.stanford.edu/dept/CTL/Newsletter/co operative.pdf

Egodawatte, G. (2010). A rubric to self-assess and peer-assess mathematical problem solving tasks of college students. Acta Didactica Napocensia, 3(1), 75-88. Retrieved from http://dppd.ubbcluj.ro/adn/article_3_1_8.pdf

Felder, R. M. \& Brent, R. (2007). Cooperative learning. In Mabrouk, P. A. (ed.). (2007). Paper at ACS Symposium Series 970, Active Learning: Models from the Analytical Sciences, (pp. 3453). Retrieved from http://www4.ncsu.edu/unity/lockers/users/f/felder /public/Papers/CLChapter.pdf

Gebhard, J. G. (2000). Teaching English as a foreign or second language. USA: The University of Michigan Press.

Geng, G. (2011). Investigation of teachers' verbal and non-verbal strategies for managing attention deficit hyperactivity disorder (ADHD) students' behaviours within a classroom environment. Australian Journal of Teacher Education, 36(7), 17-30. doi:10.14221/ajte.2011v36n7.5

Georgiadou, E., Siakas, K., \& Berki, E. (2006). Knowledge creation and sharing through student-lecturer collaborative group coursework. In Peter Feher (ed), Proceedings of 7th European Conference of Knowledge Management (ECKM06). Retrieved from http://aetos.it.teithe.gr/ siaka/down/2006 ECKM Budapest_Student_Work_Group_Georgiadou_ Siakas Berki W.pdf

Glenz, T. (2014). The importance of learning students' names. Journal on Best Teaching Practices, 1(1), 21-22. Retrieved from 
http://teachingonpurpose.org/wpcontent/uploads/2015/03/Glenz-T.-2014.-Theimportance-of-learning-students-names.pdf

Gliem, J. A. \& Gliem, R. R. (2003). Calculating, interpreting, and reporting cronbach's alpha reliability coefficient for likert-type scales. Paper presented at 2003 Midwest Research to Practice Conference in Adult, Continuing, and Community Education. Retrieved from https://scholarworks.iupui.edu/bitstream/handle/ 1805/344/gliem+\&+gliem.pdf?sequence $=1$

Harmer, J. (2007a). How to teach English. China: Pearson Education Limited.

Harmer, J. (2007b). The practice of English language teaching. Malaysia: Pearson Education Limited.

Harris, M. (1997). Self-assessment of language learning in formal settings. ELT Journal, 51(1), 12-20. doi:10.1093/elt/51.1.12

Johnson, K. (2001). An introduction to foreign language learning and teaching. England: Pearson Education Limited.

Kato, F. (2009). Student preferences: Goal-setting and self-assessment activities in a tertiary education environment. Language Teaching Research, 13(2), 177-199. doi:10.1177/1362168809103447

Kazemipour, S. (2014). Comparing the outcomes of two types of corrective feedback on EFL classes' final exam. Procedia - Social and Behavioral Sciences, 98, 876-881. doi:10.1016/j.sbspro.2014.03.495

Levine, D. R. \& Adelman, M. B. (1982). Beyond language: Intercultural communication for English as a second language. Englewood Cliffs: Prentice Hall.

Lovorn, M. G. (2008). Humor in the home and in the classroom: The benefits of laughing while we learn. Journal of Education and Human Development, 2(1), 1-12. Retrieved from http://www.scientificjournals.org/journals2008/art icles/1268.pdf

Lumpe, A. T., Haney, J. J., \& Czerniak C. M. (2000). Assessing teachers' beliefs about their science teaching context. Journal of Research in Science Teaching, 37(3), 275-292. Retrieved from

http://citeseerx.ist.psu.edu/viewdoc/download?d $\mathrm{oi}=10 \cdot 1.1 .535 .6759 \& \mathrm{rep}=\mathrm{rep} 1 \&$ type $=$ pdf

Maarof, N, Yamat, H., \& Li, K. L. (2011). Role of teacher, peer and teacher-peer feedback in enhancing ESL students' writing. World Applied Sciences Journal 15 (Innovation and Pedagogy for Lifelong Learning), 29-35. Retrieved from https://www.researchgate.net/publication/26829 0185

MacAdam, B. (1985). Humor in the classroom: Implications for the bibliographic instruction librarian. College \& Research Libraries, 327333. Retrieved from https://deepblue.lib.umich.edu/bitstream/handle/ 2027.42/93797/DB511014.pdf?sequence $=1$

Manning, S. (2006). Recognizing gifted students: a practical guide for teachers. Kappa Delta Pi Record Winter 2006 Edition. Retrieved from http://files.eric.ed.gov/fulltext/EJ724632.pdf

McKenney, S., Nieveen, N., \& van den Akker, J. (2006). Design research from a curriculum perspective. In Gravemeijer, K., (ed.). (2006)
Educational design research (pp. 110-143). Retrieved from

http://www.fisme.science.uu.nl/publicaties/literat uur/EducationalDesignResearch.pdf

Meihami, H. \& Razmjoo, S. A. (2016). An emic perspective toward challenges and solutions of self- and peer-assessment in writing courses. Asian-Pacific Journal of Second and Foreign Language Education, 1(9), 1-20. doi:10.1186/s40862-016-0014-7

Montgomery J. L. \& Baker, W. (2007). Teacherwritten feedback: Student perceptions, teacher self-assessment, and actual teacher performance. Journal of Second Language Writing, 16, 82-99. doi:10.1016/j.jslw.2007.04.002

Murphy, E. \& Manzanares, M. A. R. (2012). Rapport in distance education. International Review of Research in Open and Distance Learning, 13(1), 167-190. Retrieved from https://www.researchgate.net/publication/27943 7577

Nguyen, H. T. (2007). Rapport building in language instruction: A microanalysis of the multiple resources in teacher talk. Language and Education, 21(4), 284-303. doi:10.2167/le658.0

Özer, N., Atik, S., Şad, S. N., \& Kiş, A. (2015). Relationship between student engagement and trust in professors: a study on Turkish college students. Paper presented at ECER 2015, Budapest. Retrieved from https://www.researchgate.net/publication/29092 0141

Ozieblo, R. L. (2013). Reflections on the use of nonverbal communication in teaching Spanish to Sino-speakers. BIBLID, 19, 309-328. Retrieved from

http://www.webs.ulpgc.es/lfe/resources/Cap3RL FE19.pdf

Paul, D. (2006). Teaching English to children in Asia. Hong Kong: Pearson Education Asia Limited.

Pianta, R. C., Hamre, B. K., \& Allen, J. P. (2012). Teacher-student relationships and engagement: Conceptualizing, measuring, and improving the capacity of classroom interactions. Handbook of Research on Student Engagement, (pp. 365386). doi:10.1007/978-1-4614-2018-7_17.

Ross, J. A. (2006). The Reliability, Validity, and Utility of Self-Assessment. Practical Assessment, Research \& Evaluation, 11(10), 1-13. Retrieved from http://pareonline.net/getvn.asp? $v=11 \& n=10$

Ross, J. A. \& Bruce, C. D. (2007). Teacher selfassessment: A mechanism for facilitating professional growth. Teaching and Teacher Education, 23(2), 146-159. Retrieved from https://tspace.library.utoronto.ca/bitstream/1807/ 30029/1/Ross\%20\%26\%20Bruce\%202007b.pdf

Sánchez, C. A. G., González, B. S. G. D., \& Martínez, C. D. J. L. (2013). The impact of teacher-student relationships on EFL learning. HOW, A Colombian Journal for Teachers of English, 20, 116-129. Retrieved from https://dialnet.unirioja.es/descarga/articulo/5249 710.pdf

Scott, W. A. \& Ytreberg, L. H. (2000). Teaching English to children. USA: Pearson Education Limited. 
Srimavin, W. \& Darasawang, P. (2004). Developing self-assessment through journal writing. Proceedings of The Independent Learning Conference 2003, (pp. 1-7). Retrieved from https://www.researchgate.net/publication/22860 9049

Stamatis, P. J. (2011). Nonverbal communication in classroom interactions: A Pedagogical perspective of touch. Electronic Journal of Research in Educational Psychology, 9(3), 1427-1442. Retrieved from

http://www.investigacionpsicopedagogica.com/revista/articulos/25/englis h/Art 25 617.pdf

Steele, K. E. (1998). The positive and negative effects of the use of humor in the classroom setting (Published Thesis, Salem-Teikyo University). Retrieved from http://files.eric.ed.gov/fulltext/ED426929.pdf

Suryati, N. (2015). Classroom interaction strategies employed by English teachers at lower secondary schools. TEFLIN Journal, 26(2), 247264. doi:10.15639/teflinjournal.v26i2/247-264

Swenson, E. (2010). Rapport in the classroom. Retrieved from http://www.usma.edu/cfe/literature/swenson_10. pdf

Tinto, V. (2003). Learning better together: The impact of learning communities on student success.
Higher Education Monograph Series, 1, 1-8. Retrieved from

https://www.sdbor.edu/administrativeoffices/studentaffairs/sac/Documents/LearningBetterTogether_ Tinto.pdf

Tran, L. T. (2007). Learners' motivation and identity in the Vietnamese EFL writing classroom. English Teaching: Practice and Critique, 6(1), 151-163. Retrieved from http://files.eric.ed.gov/fulltext/EJ832183.pdf

van den Akker, J. (1999). Principles and methods of development research. In van den Akker, J., Branch, R. M., Gustafson, K., Nieveen, N., \& Plomp, T. (eds.). (1999). Design approaches and tools in education and training (pp. 1-14). doi:10.1007/978-94-011-4255-7

Webb, N. G. \& Barrett, L. O. (2014). Student views of instructor-student rapport in the college classroom. Journal of the Scholarship of Teaching and Learning, 14(2), 15 - 28. doi:10.14434/josotl.v14i2.4259

Wrenn, J. \& Wrenn, B. (2009). Enhancing learning by integrating theory and practice. International Journal of Teaching and Learning in Higher Education, 21(2), 258-265. Retrieved from http://www.isetl.org/ijtlhe/pdf/ijtlhe727.pdf 